\title{
Interdisciplinary research as methodologically and substantively creative
}

\author{
Anjala S. Krishen ${ }^{1} \cdot$ Maria Petrescu ${ }^{2}$
}

Published online: 15 February 2021

(C) The Author(s), under exclusive licence to Springer Nature Limited part of Springer Nature 2021

Interdisciplinary research while often lauded comes at a cost. While some say it is collaborative, crosses boundaries and silos, and uncovers new and creative solutions to problems, others argue that it favors shallow analysis or breadth over deep interrogation or depth. Given this, how can an interdisciplinary researcher avoid appearing unfocused? And how can society uncover creative solutions and study big problems like sustainability, privacy, racism, and climate change, without working across disciplines? Ironically, as we set out to conduct research in any field we borrow from others, often without awareness.

Philosophy of science formed the foundation of marketing theory creating the fundamental truths we use to study phenomena and make associated claims. Essentially, the search for meaning is the ultimate goal of this philosophical exploration. The underlying mechanisms by which this understanding occurred are the five senses. Rationalism led to notions of logical positivism and eventually to empiricism, the belief that knowledge about existing things is acquired through sensory experiences (Hughes 1990). Logical empiricism is a more moderate philosophy based on the original logical positivistic notions and the two terms are often intertwined in literature. Belief in reality is a key piece of the logical empiricist view (Hunt 1993; Peter 1992). The logical positivist position holds an "us" and "them" view of the world. The knowledge giver is the "us," who is setting out to prove a theory; the knowledge receivers are the "them," who are waiting to be enlightened or are the object of study. According to this view, the ontological nature of

Anjala S. Krishen

anjala.krishen@unlv.edu

Maria Petrescu

mpetrescu@monaco.edu

1 Lee Business School, University of Nevada Las Vegas, Las Vegas, NV, USA

2 Inseec U. Research Center, International University of Monaco, Principality of Monaco, Monaco reality is objective, tangible, single, ahistorical, fragmentable, and divisible. Social beings are seen as deterministic and reactive within logical positivism. With regard to epistemic assumptions, knowledge is generated using nomothetic methods and is considered time-free, context-independent, and value-free (Hudson and Ozanne 1988; Murray and Ozanne 1991).

On the other end of the philosophical spectrum (as described by most philosophy of science literature in marketing), we have interpretivism. During the eighteenth and nineteenth centuries, social change brought about a set of German idealists who agreed with the existence of a physical reality but argued that the mind is the creator and source of all knowledge. Their philosophical notion was called idealism. Deshpande (1983) discusses these two philosophical traditions as they relate to two different methodological branches - quantitative (logical positivism) and qualitative (idealism). Deshpande's central theme is that research can be furthered by use of both qualitative and quantitative methodologies. The ontological assumptions of interpretivism center on the nature of reality as socially constructed, multiple, holistic, and contextual. Within this reality, human beings are voluntaristic and proactive. Knowledge is generated using idiographic methods, and this knowledge is considered time-bound, context-dependent, and value-laden (Hudson and Ozanne 1988; Murray and Ozanne 1991). Interpretivists thus believe in a fully social constructionist view of the world, essentially that humans cannot be understood in the absence of their social environment. Thus, they believe that humans and their lives must be studied from within their surroundings not outside of them.

Perhaps academic research methodologies needed to evolve over the last few decades to augment and interrogate logical positivism and interpretivism. Researchers now conduct mixed methodology research (c.f. Krishen et al. 2014), and argue that such research is needed (Harrison 2013). In the advent of social media and the plethora of ways to explore these online portals of information, the line between 
qualitative and quantitative becomes ambiguous. Qualitative data can be analyzed with quantitative tools and methodologies such as Leximancer and NVivo and form the foundation of a follow-up quantitative study. Utilizing quantitative tools to understand qualitative data can also uncover trends, like the application of linguistic analysis to determine the brand positioning. As mentioned previously (Krishen and Petrescu 2017), the Journal of Marketing Analytics welcomes highquality interdisciplinary, mixed methodology, and creative research.

\section{References}

Deshpande, Rohit. 1983. Paradigms lost: On theory and method in research in marketing. Journal of Marketing 47: 101-110.

Harrison, R.L. 2013. Using mixed methods designs in the Journal of Business Research, 1990-2010. Journal of Business Research 66 (11): 2153-2162.

Hudson, Laurel Anderson, and Julie L. Ozanne. 1988. Alternative ways of seeking knowledge in consumer research. Journal of Consumer Research 14 (4): 508.

Hughes, J. 1990. The philosophy of social research. Harlow, Essex: Longman Group.

Hunt, Shelby. 1993. Objectivity in marketing theory and research. Journal of Marketing 57: 76-91.

Krishen, A.S., and M. Petrescu. 2017. The world of analytics: Interdisciplinary, inclusive, insightful, and influential. Journal of Marketing Analytics 5 (1): 1-4.

Krishen, A.S., R. Raschke, P. Kachroo, M. LaTour, and P. Verma. 2014. Promote me or protect us? The framing of policy for collective good. European Journal of Marketing 48 (3/4): 742-760.
Murray, Jeff B., and Julie L. Ozanne. 1991. the critical imagination: Emancipatory interests in consumer research. Journal of Consumer Research 18 (2): 129.

Peter, J. 1992. Realism or relativism for marketing theory and research: A comment on hunt's "scientific realism." Journal of Marketing 56: $72-79$.

Publisher's Note Springer Nature remains neutral with regard to jurisdictional claims in published maps and institutional affiliations.

Anjala S. Krishen is a Professor of Marketing and International Business and Director of MBA Programs at University of Nevada, Las Vegas, and has a B.S. in Electrical Engineering from Rice University, and an M.S. Marketing, MBA, and Ph.D. from Virginia Tech. She held management positions for 13 years before pursuing a doctorate. As of 2021, she has published over 60 peer-reviewed journal papers in journals including Journal of Business Research, Psychology \& Marketing, Information \& Management, European Journal of Marketing, Journal of Travel \& Tourism Marketing, and Journal of Marketing Education. In 2016, she gave a TEDx talk (at UNR) titled "Opposition: The light outside of the dark box," and a UNLV Creates speech entitled "Consuming to Creating, Watching to Doing, Seeing to Being." To date, she has completed over 65 marathons, seven ultramarathons, and four 100 milers, and has a black belt in Taekwondo.

Maria Petrescu is an Associate Professor of Marketing at International University of Monaco, Inseec U. Research Center. Her main research areas include marketing analytics and digital marketing. She has published articles in journals such as Psychology \& Marketing, the Journal of Marketing Management, Public Management Review, Journal of Product and Brand Management, the Journal of Retailing and Consumer Services, and the Journal of Internet Commerce. 